Jurnal Administrasi Publik (Public Administration Journal), 10(1) June 2020

ISSN 2088-527X (Print) ISSN 2548-7787 (Online), DOI: https://doi.org/10.31289/iap.v10i1.3390

Journal Administrasi Publik

(Public Administration Journal)

Available online http://ojs.uma.ac.id/index.php/iap

\title{
Analysis of the Implementation of Groundwater Tax on Dewatering in Jakarta
}

\author{
Agustina* \& Inayati** $^{*}$ \\ Tax Policy \& Administration, Faculty of Administration Sciences, \\ Universitas Indonesia, Indonesia
}

Received: January 21, 2020; Aceppted: March 21, 2020; Published: May 8, 2020

Corresponding Email:* tina.tin06@gmail.com \&** inayati.hifni01@gmail.com

\begin{abstract}
This article aims to analyze the implementation of groundwater tax on dewatering in DKI Jakarta Province and the factors causing the collection of groundwater tax on dewatering are not optimal in DKI Jakarta Province. The problem is focused on the ground water tax policy on dewatering in DKI Jakarta Province. To approach this problem, the theory of Merilee Grindle's about policy implementation was used. Data were collected through literature study and field study and analyzed qualitatively. Through this method, data and information obtained from field studies and literature studies were then processed to draw conclusions. This study concludes that there are interests that are affected in the implementation of groundwater tax on dewatering, especially the interests of the Regional Tax and Retribution Agency. It is related to the desired benefits of implementing the policy, namely increasing groundwater tax revenues in DKI Jakarta Province. Some factors caused the implementation of ground water tax on dewatering were not optimal are human resources that are still lacking in terms of quality and quantity, data collection and supervision have not been done well, lack of coordination between related agencies, lack of socialization and unclear implementation regulations.
\end{abstract}

Keywords: Dewatering, Groundwater Tax, Tax Revenue

How to Cite:Agustina \& Inayati. (2020). Analysis of Implementation of Groundwater Tax on Dewatering in Jakarta. Jurnal Administrasi Publik (Public Administration Journal). 10(1): 83-91 


\section{INTRODUCTION}

Water is a limited natural resource. Excessive extraction and use of groundwater causes the groundwater supply to run low and land subsidence to cause landslides. One of the efforts of the DKI Jakarta Government to control excessive extraction and use of ground water is to impose a ground water tax on individuals or agencies that take, utilize or extract and utilize groundwater. DKI Jakarta Regional Regulation Number 17 of 2010 regulates the Groundwater Tax.

Table 1. Development of the Number of Groundwater Taxpayers in DKI Jakarta Province in 2011 to 2016

\begin{tabular}{lllllll}
\hline City Administration & 2011 & 2012 & 2013 & 2014 & 2015 & 2016 \\
\hline South Jakarta & 1,312 & 1,363 & 1,398 & 1,469 & 1,532 & 1,620 \\
East Jakarta & 836 & 854 & 854 & 906 & 939 & 951 \\
Central Jakarta & 579 & 590 & 597 & 613 & 652 & 686 \\
west Jakarta & 498 & 517 & 531 & 563 & 591 & 611 \\
North Jakarta & 418 & 425 & 425 & 435 & 437 & 452 \\
\hline Total & $\mathbf{3 , 6 4 3}$ & $\mathbf{3 , 7 4 9}$ & $\mathbf{3 , 8 0 5}$ & $\mathbf{3 , 9 8 6}$ & $\mathbf{4 , 1 5 1}$ & $\mathbf{4 , 3 2 0}$ \\
\hline
\end{tabular}

Source: data.jakarta.go.id

In table 1 , the number of groundwater taxpayers in Jakarta presented is increasing every year. The conflicts in water extraction and water use also occur in suburban Kathmandu, Nepal. The increasing pressure on land and the increasing water demand of a growing population in the Kathmandu Valley creates new patterns of water use and water-related conflicts (Shrestha, Roth \& Joshi, 2018).

Implementation Regulation related to ground water tax is Governor Regulation No. 38 of 2017 where in article 3 paragraph 1 is mentioned that the groundwater extraction and/or its utilization is dewatering. For example in the Jakarta Garden City project with an area of $3847.12 \mathrm{~m} 2$ needs five dewatering wells, five recharging wells, and five piezometers (monitoring wells), with water discharge issued for one month are 3,990 cubic meters (Imamuddin, 2018).

Discharge of water taken can have an impact on environmental damage so it is interesting for researchers to analyze the contribution made to the area due to groundwater taking. Dewatering is an object of the ground water tax, but in practice not all dewatering is subject to a ground water tax. According to Grindle (1980), there are two general questions in research of public policy implementation. First is the effect of policy content on its implementation. The second is about context, namely how the political context influences policy implementation.

In the content of the policy, dewatering is an object of the ground water tax, but practically not all dewatering is subject to a ground water tax. In terms of policy context, groundwater tax collection for dewatering is carried out by the Tax Service Unit and Regional Retribution in collaboration with the One-Stop Integrated Services and Investment Office and Industry and Energy Office of DKI Jakarta Province.

The previous literature review was a study conducted by RR Mayang Ayu Puspitasaheti in 2015. This study was entitled Formulation of Policy on Increasing Raw Water Price (HAB) as an Effort to Improve the Regular Function of Groundwater Tax in Bandung. The research method used in this study was qualitative. In this study, the four stages of the formulation of the policy of Increasing Raw Water Prices in Bandung were described, namely the preparation stage, the analysis stage, the reporting stage and the mayor drafting stage.

The next literature review is from a journal at the National Seminar on Science 
and Technology 2018, Faculty of Engineering, Muhammadiyah University, Jakarta October 17, 2018 by Mohammad Imamuddin entitles Dewatering Analysis in Basements (Case Study of the Jakarta Garden City Building Project in East Jakarta). The research method used was a field survey. Imamuddin's research focuses on technical calculations regarding dewatering work.

The difference between this study and previous research is this study aims to analyze the implementation of groundwater tax on dewatering in DKI Jakarta Province and analyze the factors causing groundwater taxation on dewatering is not yet optimal in DKI Jakarta Province.

\section{RESEARCH METHODS}

This study used a post-positivist approach and qualitative methods. The Post-positivist approach holds a philosophy where the cause determines the effect or outcome (Cresswell, 2014). The research method used was a qualitative method, where researchers design research, collect data, analyze data, and interpret data simultaneously (Neuman, 2014).

Data collection was carried out in this study using two ways, namely literature study and field studies. The study was conducted by collecting and studying data and information from books, undergraduate theses, postgraduate theses, articles, journals from the internet and domestic tax regulations. Field studies were carried out by gathering data and information through in-depth interviews using interview guidelines to obtain primary data.

Analyzing the data means to organize systematically, integrate, look for patterns and relationships between data and information obtained. To analyze, the researchers related the data with concepts, generalized, and identified the themes. The analysis made it possible to increase understanding, broaden theories, and advance knowledge. Data analysis looked for patterns in data - repetitive behavior, objects, phases, or ideas. Having identified a pattern, it is necessary to interpret it in the social theory where the event took place (Neuman, 2014).

\section{RESULTS AND DISCUSSION Implementation of groundwater tax on dewatering in DKI Jakarta Province}

The construction of a basement that performs dewatering required a lot of ground water extraction or removal. From the data obtained from the One-Stop Integrated Services and Investment Office, dewatering licenses issued in 2017 and 2018 are:

Table 2. List of Dewatering Permits in DKI Jakarta Province in 2017 and 2018

\begin{tabular}{llll}
\hline Description & 2017 & 2018 & \\
\hline New & 83 & 29 & \\
Extension & 8 & 16 & \\
\hline Total & 91 & 45 & \\
\hline Source: One-Stop & Integrated & Service & and
\end{tabular}
Inverstment Office

The process of issuing a dewatering permit at the One-Stop Integrated Services and Investment Office is based on the Decree of the Head of the One-Stop Integrated Services and Investment Office of DKI Jakarta Province Number 129 of 2017 concerning Licensing Process Flow in the Field of Spatial Planning, Environmental Studies and Development.

The ground water tax on dewatering is a regional tax whose authority lies with Tax and Retribution Agency in DKI Jakarta Province, with the rates stipulated in the Regional Regulation in DKI Jakarta Province and the proceeds used for development in DKI Jakarta Province. Data on groundwater tax revenues in DKI Jakarta Province in 2017 and 2018 are presented in the table below. 
Table 3. Revenue of Groundwater Tax in DKI Jakarta Province in 2014-2018

\begin{tabular}{|c|c|c|c|}
\hline Year & Groundwater Tax Target & Groundwater Tax Receipts & $\begin{array}{l}\% \\
\text { Achievement }\end{array}$ \\
\hline 2014 & $120,000,000,000$ & $95,818,763,693$ & $79.85 \%$ \\
\hline 2015 & 95,000,000,000 & $104,929,684,748$ & $110.45 \%$ \\
\hline 2016 & 110,000,000,000 & $112,399,412,732$ & $102.18 \%$ \\
\hline 2017 & 100,000,000,000 & $96,679,543,773$ & $96.68 \%$ \\
\hline 2018 & $145,000,000,000$ & $106,495,794,526$ & $73.45 \%$ \\
\hline
\end{tabular}

From the table above, it is known that the realization of groundwater tax revenues in 2017 and 2018 has not reached 100\%. From these data, researchers conducted an analysis of the implementation of the ground water tax in DKI Jakarta. Implementation of policies is very important for the success of a government. Even though the political system is fair, the goals are good and the organizational structure is very strong, no policy can be successful if the implementation part does not meet the standards (Yadav, 2010).

Researchers analyzed the implementation of groundwater tax on dewatering to local tax revenue using Grindle theory. Based on Grindle (1980), in achieving the objectives of a policy, activities to implement the policy are influenced by:

1. Content Policy consists of interest affected, type of benefit, extent of change envisioned, site of decision making, program implementers, and committed resources.

2. Context of Implementation (Policy relations) consists of power, interest and strategies of actors involved (power, interests and strategies of actors involved), institution and regime characteristics, and compliance and responsiveness.

The researcher analyzed the implementation of ground water tax on dewatering from the theory as explained in this study.

\section{Interest Affected}

Interest Affected relating to various interests that are affected by policy. Interest affected means the extent to which those interests are accommodated in the contents of a policy.

Every policy intervention and act of law is about providing, distributing and regulating ". Regulation can be understood as part of governance, which is about directing the events and behavior (Hirschauer, Lehberger \& Musshoff, 2015).

Interests affected in the implementation of the ground water tax on the first dewatering are the Regional Tax and Retribution Agency as the party that collects groundwater tax on dewatering. The Interest affected is then related to the Department of Industry and Energy as the party that installs water meter recording devices. In this case, the Department of Industry and Energy supervised water discharges that are issued or moved to comply with the plans contained in the permit approved by the One-Stop Integrated Services and Investment Office. The interests of the One-Stop Integrated Services and Investment Office in this case are related to licensing of dewatering. The interests of other parties affected are the construction organizers who carry out the dewatering. The companies or agencies affected in proposing permit for dewatering also paid the groundwater tax on dewatering.

The interest affected in the Regional Tax and Retribution Agency in this case is the Regional Tax and Retribution Service Unit (UPPRD) as the unit that has the authority to collect ground water taxes, one of them is in the UPPRD Menteng where in 2018 as many as 14 tax objects were taxable on groundwater tax on dewatering. It was obtained from the data collection in the field as well as 
coordination with the Department of Industry and Energy and the One-Stop Integrated Services and Investment Office.

\section{Type of benefit}

Type of benefit means a policy must be able to provide several benefits that have a positive impact when implemented. The expected benefit of the ground water tax policy on dewatering for the Regional Tax and Retribution Agency is the contribution of the receipt of ground water tax through the addition of the ground water tax object from dewatering activities. It is in line with the function of tax as a source of safe and sustainable state revenue. As stated Rosdiana \& Irianto (2014) as follows "The main tax function is as a source of state revenue, to increasing the state treasury."

Ground water that was taken continuously caused environmental damage in the form of a decrease in groundwater. In the construction project for buildings on 5 floors using dewatering is to control water that can disturb the course of a project. It is in line with what was stated by Asiyanto (2010): "The purpose of dewatering is to be able to control water both ground water and surface water, so as not to disturb or to block the process of carrying out a construction, especially for the implementation of structural parts located in the soil and under ground water."

Although dewatering is something that must be done in a construction, negative externalities arising from the extraction or removal of ground water with a large amount of discharge can still be avoided. The ground water tax is one of the government's efforts to control it. It is as revealed by Pigou known as Pigouvian Tax.

Pigouvian Tax is motivated by externalities, that is consuming goods that harm others, people will consume too much if the market does not make rules. The taxes imposed on goods with negative externalities can increase welfare by reducing consumption to an efficient level where marginal social costs equal to marginal social benefits. In addition, people sometimes ignore harmful or beneficial effects for themselves, for example due to misinformation, or do not fully consider future consequences due to current focus (Allcott, Lockwood \& Taubinsky, 2019).

Water and air is traditional examples of free goods in the economic field. Through Pigouvian Tax, economists argue, more pollution control can be obtained with the same expenditure (Ghaleigh, 2013). This tax links the distribution goals and environmental policies with public costs. On the one side, it affects the optimal environmental tax rate and on the other side it is a distribution function (Aigner, 2014). In addition, this tax aims to harmonize prices to eliminate social and personal costs that are a result of externalities (Taylor et al, 2014).

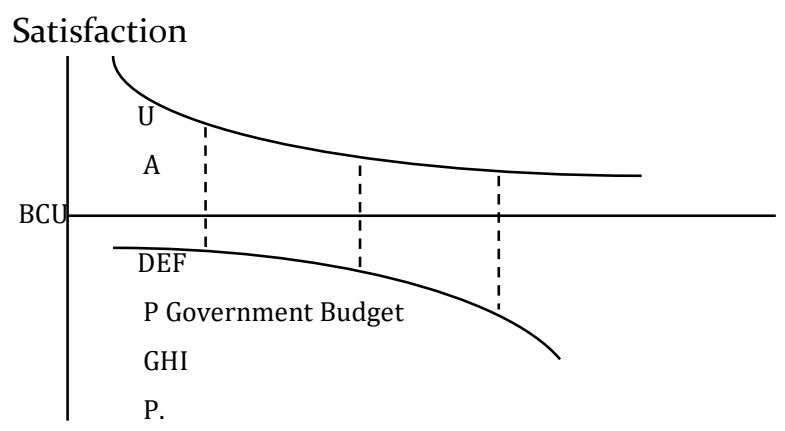

Figure 1. Optimal Supply and Financing of Public Goods According to Pigou

Source: Mangkoesoebroto (1999)

From the picture above, the marginal satisfaction curve is shown by the UU curve. This shows that the more public goods produced, the lower the marginal satisfaction of the community. The PP curve is a marginal dissatisfaction curve. At point $\mathrm{F}$ marginal satisfaction with public goods is less than public dissatisfaction with tax payments. It indicates that public goods produced in small amounts can improve people's welfare by increasing the 
budget to produce public goods (Mangkoesoebroto, 1999).

It occurs in the extraction and / or utilization of ground water in dewatering. The impact of this activity is the empty cavity in the soil that should be filled with water which in the long run can reduce the surface of the soil. The ground water tax levied on dewatering activities was one of the government's efforts to deal with the negative externalities impact arising from these activities. The results of the ground water tax can be used by the Regional Government in this case the DKI Jakarta Province to restore the environment that has been damaged by dewatering activities.

Externalities can also be seen from the byproducts that pollute from economic activities can easily be sent to other companies, which operate decontamination. It is clearly a case of solid and hazardous waste. Transportation, maintenance and disposal depend on since several years they are on private service providers. The same things applies, of course, to the disposal and treatment of wastewater (Sans, Schwartz \& Stahn, 2019).

\section{Extent of Change Envisioned}

Extent of change envisioned is the content of a policy affecting its implementation. The ground water tax on dewatering whose effect on the environment is only visible in the long term, but the effect on groundwater tax revenues in DKI Jakarta Province can be seen in its realization every year. The change envisioned is an increasing in groundwater tax revenues in DKI Jakarta Province.

\section{Site of Decision Making}

It is the extent to which implementation activities are decentralized or controlled by the bureaucracy. Each decision considers who has the authority to make decisions and have an impact on the implementation of a policy. At this point we want to identify the change envisioned of a policy must have a clear scale. Decision making on the ground water tax policy on dewatering was at the Head of the Regional Tax and Retribution Service Unit in each sub-district in DKI Jakarta Province.

The location of decision making must be in clear location since it will affect the implementation of the policy. In collecting groundwater tax on dewatering, decision makers in each institution involved in dewatering must be clear so that the implementation of the policy runs smoothly.

\section{Program Implementers}

Program implementers have an important role in implementing a program, so that policy implementers must have competence that supports in accordance with their duties and responsibilities.

The ground water tax policy on dewatering is a policy that aims to increase groundwater tax revenue which is the Original Revenue of the DKI Jakarta Province. In its implementation, the collection process or flow must be clear so that implementers have no difficulty in understanding and implementing the policy. The policy of collecting ground water tax on dewatering is the authority of the Regional Tax and Levies Agency where the authority is delegated to the Regional Tax and Levies Service Unit.

\section{Committed Resources (Resources Used)}

In implementing policies it must be supported by adequate resources. These resources include human resources, facilities, infrastructure, and also finance so that the policy implementation can run well.

Implementation of the ground water tax policy on dewatering involves several agencies. At the Regional Tax and Levies Agency, each Regional Tax and Levies Service Unit is given the authority to collect ground water taxes including dewatering. In its implementation in each Regional Tax and Levies Service Unit, there is only one head of the data collection unit 
and one to two data staff who supervise the Regional Tax and Levies Service Unit to collect local taxes including the ground water tax on dewatering. Besides it, supporting facilities for collecting ground water tax on dewatering is the Ground Water Tax system.

\section{Power, Interest and Strategies of Actors Involved}

Political elites used society to follow the political parties' wishes or become a means for the community to express their aspirations. Often, the goals of the actors are in conflict with each others.

It is similar to policy in dealing with climate change and environmental problems in California. The government in California was catching up with politics by examining better designs of climate policy instruments such as clean energy standards, subsidies for green technology, and other approaches. (Schmalensee \& Stavins, 2019).

The power, interests and strategies of the actors involved in a policy need to be taken into account so that the implementation of the policy can be implemented properly. The interest of the Regional Retribution and Tax Agency in terms of the ground water tax policy on dewatering is to increase tax revenue as local revenue. This interest is closely related to the power or authority possessed by the Regional Tax and Retribution Agency in the scope of the collection of ground water taxes that cannot be separated from the coordination with the Department of Industry and Energy as well as the Office of Investment and One Stop Integrated Services.

\section{Institution and Regime Characteristics (Institutions and Characteristics of Regimes in Power)}

The success of a program is influenced by the priorities of political officials or the results of other programs. The structure of political institutions and the type of regime in which a policy or program is implemented influences the successful implementation of the policy.

The policy of the authorities has a big impact on the daily lives of citizens. Most developing countries such as Indonesia have a broad and active public sector that is involved in many aspects of economic and social life, and the state bureaucracy is one of the strongest institutions in society. The ground water tax policy on dewatering is implemented by the Regional Tax and Levies Agency through the Regional Tax and Levies Service Unit in collaboration with the One-Stop Integrated Service and Inverstment Office and the Department of Industry and Energy.

\section{Compliance and Responsiveness}

The problem in achieving policies and objectives of a program is regarding the response or response as well as compliance. This response is needed in order to evaluate and support a policy program. In achieving policy objectives, the officials face two subordinate issues that highlight the interaction of the program environment and program administration.

In terms of compliance, seen from the perspective of the dewatering organizer, the level of compliance was still lacking. Data obtained from the One-Stop Integrated Service and Investment Office, the dewatering permit issued in 2018 was 45 permits. However, only a part of the groundwater tax on dewatering was collected. This is because dewatering was less informed so that the dewatering organizer did not know that the implementation of dewatering is an object of ground water tax. From the Regional Tax and Levies Agency, in this case the Regional Tax and Levies Service Unit still did not understand deeply about the dewatering activities which are the first step in construction work, so that some dewatering operations escape from groundwater tax collection. 


\section{Factors that Cause Groundwater Taxation on Dewatering are Not Optimal in DKI Jakarta Province}

In its collection, the ground water tax on dewatering was still an unfamiliar thing in the community. Dewatering specifically leads to building construction work, so socialization was needed in the implementation of the collection. There is a need for supporting information through socialization so that the public, especially construction providers who carry out dewatering, can understand their obligations to pay taxes.

A similar incident occurred in Tunisia, that is the theft of water in agriculture. Cooperatives have a role in dealing with water theft where given a high penalty rate to reduce the occurrence of water theft. The level of this penalty depends on the costs incurred due to water theft. In addition, the Tunisian government provided incentives to farmers. Improving agricultural technology and increasing costs for monitoring have a positive impact in reducing water theft in Tunisia. (Mattoussi \& Seabright, 2014).

Data collection to the field to check projects needs to be done to increase the number of tax objects that have the potential to increase groundwater tax revenues for dewatering. This data collection needs to be supported by adequate human resources. Collection of groundwater tax on dewatering requires qualified and competent human resources.

\section{CONCLUSION}

The implementation of ground water tax policy on dewatering was analyzed from the theory of Merilee Grindle in terms of policy content / content, namely the interest affected include the Regional Retribution and Tax Agency, the One-Stop Integrated Service and Investment Office, the Industry and Energy Office and the Dewatering Provider. The types of benefit were in the form of an increasing in groundwater tax revenue can be achieved with the collection of ground water tax on dewatering. The extent of change envisioned is the awareness enhancement of the dewatering organizers to report their activities and fulfill tax obligations. The site of decision making is the clarity of the decision makers in each relevant authorized agency in the collection of groundwater tax on dewatering. Program implementers were still not supported by adequate quality and quantity in the implementation of groundwater tax collection on dewatering. Resources used in the form of facilities and infrastructure were still inadequate.

In terms of the policy context namely power, interests and strategies of the actors involved wre still not aligned with the objectives of the ground water tax policy on dewatering to increase local tax revenue. The characteristics of the ruling institutions and regimes still prioritized the interests of each agency. The level of compliance was still low in implementing the ground water tax policy on dewatering and the low response of the policy implementers.

Factors that caused the implementation of ground water tax on dewatering were not optimal in DKI Jakarta Province are human resources that are still lacking in terms of quality and quantity, have not done good data collection, have not done supervision and coordination with agencies related to sustainable, tax information dissemination ground water for dewatering has not been done well, the implementing regulations related to the collection of ground water tax for dewatering were still unclear.

\section{BIBLIOGRAPHY}

Aigner, R. (2014). Environmental Taxation and Redistribution Concerns. FinanzArchiv/ Public Finance Analysis, 70(2): 249-277.

Allcott, H. Lockwood, B.B. \&Taubinsky, D. (2019). Should We Tax Sugar-Sweetened Beverages? An Overview of Theory and Evidence. The Journal of Economic Perspectives, 33(3): 202227 
Asiyanto. (2010). MetodeKonstruksi Dewatering. Jakarta: PenerbitUniversitas Indonesia (UIPress)

Cresswell, J.W. (2014). Research Design Qualitative, Quantitative, and Mixed Methods Approach 4th Edition. London: SAGE Publications Ltd.

Ghaleigh, N.S. (2013). Two Stories about EU Climate Change Law and Policy. Climate Change: International Law and Global Governance Book Subtitle: Volume I: Legal Responses and Global Responsibility.

Grindle, M.S. Edition (2017). Politics and Policy Implementation in the Third World. New Jersey: Princeton University Press

Hirschauer, N. Lehberger, M.\&Musshoff, O. (2015). Happiness and Utility in Economic Thought Or: What Can We Learn from Happiness Research for Public Policy Analysis and Public Policy Making? Social Indicators Research, 121(3): 647-674.

Imamuddin, M. (2018). Analisis Dewatering pada Basement (StudiKasusProyek Gedung Jakarta Garden City). Seminar Nasional Sains dan Teknologi 2018. Fakultas Teknik Universitas Muhammadiyah Jakarta. 17 Oktober 2018.

Mangkoesoebroto, G. (1999). Ekonomi Publik Edisi Ketiga. Yogyakarta: BPFE-Yogyakarta.

Mattoussi, W \& Seabright, P. (2014). Cooperation against Theft: A Test of Incentives for Water Management in Tunisia. American Journal of Agricultural Economics, 96(1): 124-153.
Newman, W.L. (2014). Social Research Methods: Qualitative and Quantitative Approaches 7th Edition. England: Pearson Education Limitied.

Puspitasaheti, Rr.M.A. (2015). Formulasi Kebijakan Kenaikan Harga Air Baku (HAB) sebagai Upaya Peningkatan Fungsi Regulerend Pajak Air Tanah di Kota Bandung.Skripsi. Jakarta: Universitas Indonesia.

Rosdiana, H. \&Irianto, E.S. (2014). Pengantar Ilmu Pajak - Kebijakan dan Implementasi di Indonesia. Jakarta: PT Raja GrafindoPersada.

Sans, D. Schwartz, S \& Stahn, H. (2019). On Outsourced Abatement Services: Market Power and Efficient Regulation. Annals of Economics and Statistics, 136: 55-78.

Schmalensee, R \&Stavins, R N. (2019). Policy Evolution under the Clean Air Act. The Journal of Economic Perspectives, 33(4): 27 50.

Shrestha, A. Roth, D \& Joshi, D. (2018). Flows of Change Dynamic Water Rights and Water Access in Peri-urban Kathmandu. Ecology and Society, 23(2)

Taylor, R.G. Schmidt, R.D. Stodick, L \&Contor, B.A. (2014). Modeling Conjunctive Water Use as a Reciprocal Externality. American Journal of Agricultural Economics, 96(3): 753768.

Yadav, S. (2010). Public Policy and Governance In India: The Politics of Implementation. The Indian Journal of Political Science, 71(2): 439-457 